\title{
The landlords, the peasant, and the retention basin: Local political ecology of water management in the small island of Semau, Kupang, Indonesia
}

\author{
PANTORO TRI KUSWARDONO ${ }^{1, \vartheta}$, I WAYAN MUDITA ${ }^{1,2}$, DAVID B.W. PANDIE ${ }^{1,3}$ \\ ${ }^{1}$ Department of Environmental Science, Graduate Program, Universitas Nusa Cendana. Jl. Adisucipto Penfui, Kupang 85001, East Nusa Tenggara, \\ Indonesia, "email: torry.kuswardono@gmail.com \\ ${ }^{2}$ Faculty of Agriculture, Universitas Nusa Cendana. Jl. Adisucipto Penfui, Kupang 85001, East Nusa Tenggara, Indonesia \\ ${ }^{3}$ Faculty of Social and Political Science, Universitas Nusa Cendana. J1. Adisucipto Penfui, Kupang 85001, East Nusa Tenggara, Indonesia
}

Manuscript received: 9 January 2021. Revision accepted: 2 May 2021.

\begin{abstract}
Kuswardono PT, Mudita IW, Pandie DBW. 2021. The landlords, the peasant, and the retention basin: Local political ecology of water management in the small island of Semau, Kupang, Indonesia. Intl J Trop Drylands 5: 12-19. Freshwater is the most fundamental issue in small islands because of very small catchment area and low water retention capacity. To ensure water availability for domestic and agriculture purposes, the Government of Indonesia (GoI) has built hundreds of retention basins in all islands in East Nusa Tenggara Province from 1985 until recent times. In the small island of Semau where the study is undertaken, the availability of more than 24 retention basins did not solve freshwater problem. Inequality of distribution and usage of water from retention basin has become latent issues for more than 20 years. Under water provision program of GoI, all small retention basin management has been handed over to local community to become common pool resources (CPR). However, retention basin as CPR is not happening as expected. Using the Social-Ecological System Framework (SESF), the study found that one of the Governance components of SESF, i.e. property rights, is the key problem in achieving CPR. Informants from 5 villages interviewed and involved in focused group discussions consistently mentioned the word landlord in stories of water conflict, sabotage, and exclusion of access to water. The word landlord implied a tenurial or property rights system. A landlord had the traditional rights as a land custodian of the retention basin and all resources on his lands. The findings suggested that further investigation of the tenurial system and its transformation is needed whenever a vital construction such as retention basins would occur. In the past, the landlord would wisely distribute land and water as social goods so each person living in his ancestral land would not suffer from hunger. The construction of new retention basins could tran sform the roles of a landlord from a land custodian into a land owner and transform common-pool resources into private goods.
\end{abstract}

Keywords: Commons, common-pool, political-ecology, social-ecological system, tenurial

\section{INTRODUCTION}

The importance of studying small islands is not merely because of their vulnerability to climate change particularly in regard to sea-level rise which might cause them to be sinking (Solomon 2007). Instead, there is another eminent problem regarding fresh-water availability which has actually been recognized since early nineties. Some small islands have or limited fresh-water supply because of their geological formation, shape and small catchment area (Falkland and Custodio 1991). Since they cannot depend on the natural hydrological cycle, water catchment infrastructure needs to be built to address freshwater challenges. Alternatively, advanced technologies, such as seawater desalination installation, need to be placed to provide freshwater for its dweller (Falkland dan Custodio 1991).

According to Falkland (1991), a small island is a land with an area of fewer than $2000 \mathrm{~km}^{2}$ (200,000 ha) or has a wide distance between one side to another side is less than 10 km (Falkland and Custodio 1991; UU no 1 Year 2014, n.d.). As a consequence, small island has a limited water catchment area, a very small basin and a short drainage system (Falkland and Custodio 1991). Therefore, water retention times of small island is very short. Rainwater can easily flow to the sea without infiltrating or dwelling on the land.

In Indonesia, particularly in East Nusa Tenggara (Nusa Tenggara Timur, NTT) Province, the Government of Indonesia (GoI) has been implementing freshwater provision program by developing rainwater retention basins in the areas where freshwater is limited. From 1985 until 2014 in all over the province, GoI has built 832 retention basins including in small islands such as Rote, Sabu, Lomblen, Pantar, and Semau (Balai Wilayah Sungai Nusa Tenggara II, n.d.). Even though hundreds of retention basins have been built, the numbers are inadequate to fulfill the need for freshwater of whole island. In 2017, Senator Ibrahim Agustinus Medah asked central government to spare $10 \%$ of 30,000 national programs on retention basins to be built in ENT Province alone (Kompas Cybermedia 2017). Not so long before Medah, Member of Parliament, Fary Francis, also encouraged central government to develop retention basins to increase freshwater reserve both for domestic use, agriculture, and cattle raising (Kompas 2017).

Although the development of retention basins is considered a solution to increase freshwater reserve, several studies on sustainability of retention basins showed that retention basins are not effective (Bunganaen 2013; Notoatmojo and Rivai 2001; Pradhan et al. 2011; Triastono 
and Lidjang 2007). For example, Triastono and Lidjang (2007) and Bunganaen (2013) explained that water volume of retention basins in Timor was only $40-60 \%$ of its capacity on average. Most of the retention basins studied have high sedimentation because of lack of management at catchment areas. Both studies concluded that there is no governance at micro basin to prevent sedimentation of each retention basin.

Another problem related to underperformance of retention basins is operation and maintenance (O\&P). A study by Bunganaen (2013) and Triastono and Lidjang (2007) showed that O\&P is the worst aspect in the management of retention basin. All retention basins studied don't have organizations or institutions responsible for maintaining the basin performance to provide optimum services. Whereas, after a retention basin is built, the government transfers the basin management to the local community. It was expected that a self-governing system could be emerged and be established to sustainably manage the basin (Pradhan et al. 2011; Triastono and Lidjang 2007).

Aside from technical and institutional problems, conflicts among communities also emerge in many retention basins. Ratumakin (2016) mentioned that tensions and conflicts related to water resources occurred in $15 \mathrm{sub}-$ district in Kupang District. Ratumakin (2016) recorded the tensions and conflicts among those who claim on ancestral land (landlords) and commoners. The landlords usually use customary rights of land to exclude commoners when accessing water from retention basins built for public. Occurrence of tensions and conflicts on access to water particularly from built infrastructure is likely to be common in East Nusa Tenggara. And most of the findings involve actors such as landlords. Regarding indication that the conflicts over water resources are likely to involve landlords and commoners, it raised question of whether customary control over land is the prominent factor of the conflict? It is also interesting to Ratumakin (2016) findings that natural water resources, such as springs or old wells, are less likely to become the center of conflicts and tensions. Most of the tensions happened inbuilt infrastructure such as retention basin. The study aimed to understand the difference between power and values of landlords regarding water resources. The research questions are: to what extent the landlords would play their roles and power to water resources? Is there an evolution of roles, powers, and values of local actors over water resources? The last question is the impact of these power games on the sustainability of retention basin in terms of stability of water reserve and equity of access.

\section{MATERIALS AND METHODS}

\section{Study area}

The study area is located in Semau Island, Kupang District, East Nusa Tenggara Province, Indonesia, a small island with an extent of 26,750 ha. Semau Island is a semiarid island according to Schmidt and Oldeman climate classification (Type E and F) (Kaho 2019). Semau has rainfall of less than $1100 \mathrm{~mm}$ per year, lesser than western part of Indonesia (Kaho 2019). The population of the island in 2018 is 12,776 inhabitants. Most of the inhabitants are dryland farmers planting maize, paddy, and horticulture. Shallots and chili are the main agricultural crops, making Semau the largest producer of shallots (BPS Kabupaten Kupang 2019). Demand for water for shallots planting in dry season is high. Community mostly use retaining basins. The small island also consists of more than 9000 cows (Bos javanicus) owned by the island inhabitants (BPS Kabupaten Kupang 2019).

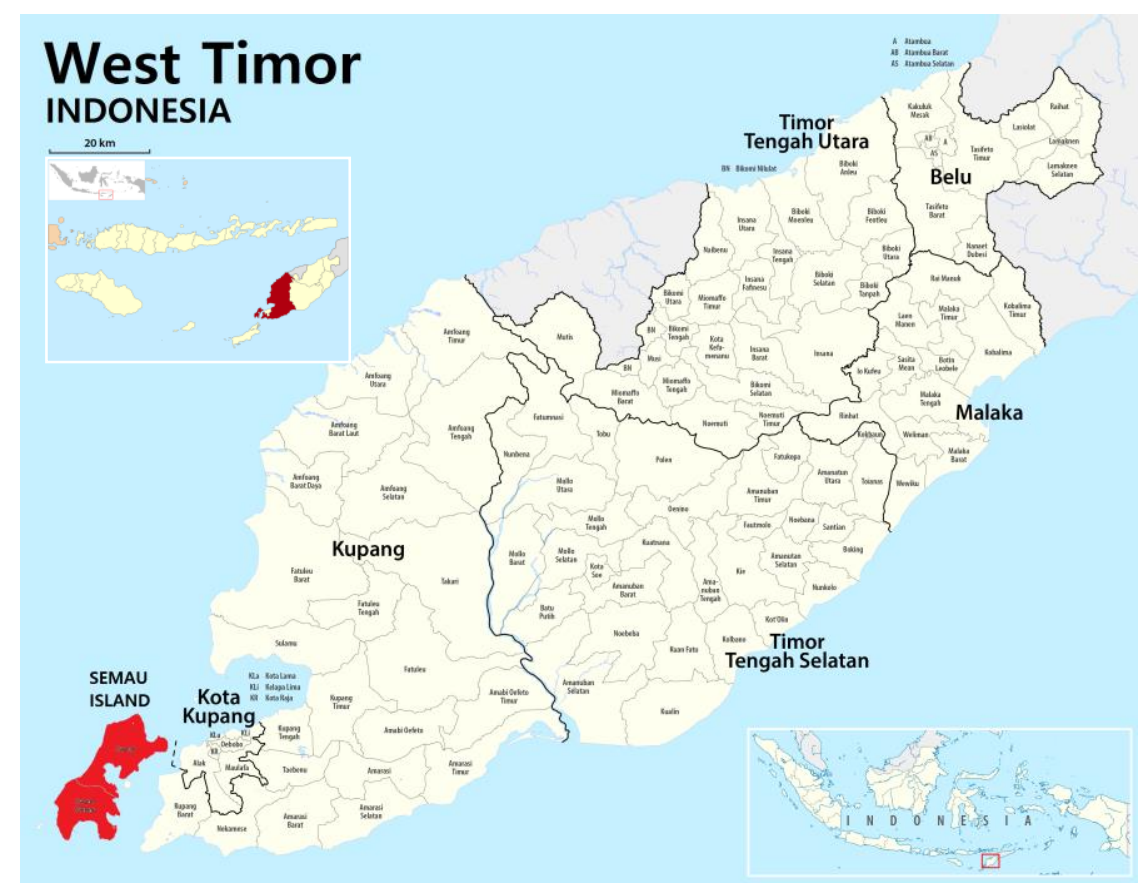

Figure 1. Map of the study area in Semau Island, Kupang District, East Nusa Tenggara Province, Indonesia 
Semau Island has more than 34 retention basins built since 1985 to 2016 (Balai Wilayah Sungai Nusa Tenggara II, n.d.). The development of retention basins is still going on now. According to the design, all of the retention basins in Semau are multipurpose basins. They provide water for domestic use, agriculture, and cattle raising. Villages in north of Semau have more retention basins from the south. Twenty-six retention basins were built from 1985 until 2016 in the northern part of the island.

The study was undertaken in 4 villages, namely Hansisi, Uiasa, Huilelot, and Batuinan, where most of the retention basins were built since 1985 . There were two reasons for the study undertaken in these 4 villages. First, the villages represent the age of retention basins. Uiasa and Hansisi villages have the oldest retention basins built before regional autonomy was placed in 2000. While Batuinan and Huilelot represent newer basins that were built after regional autonomy era in 2000 .

Secondly, the 4 villages have different sub-ethnic groups with different kinds of tenurial systems. Hansisi represents a fully Rotenese sub-ethnic, Huilelot represents two cultures of Rotenese and Helong, while Batuinan and Uiasa represent a fully Helonese sub-ethnics.

\section{Conceptual framework}

Retention basin is one of the oldest infrastructures to harvest rainwater in the world (Boers 1986). It is also the easiest infrastructure to build on small islands (Falkland dan Custodio 1991). Retention basins can also be an indicator regarding sustainable management of microbasins because the sustainability of retention basins depends on their water catchment areas (land cover). A high rate of sedimentation of retention basins indicates that the upper area of the basin is disturbed (Ali et al. 2010; Kerr 2007).

A retention basin is socio-ecological system. Berkes and Folke (1994) explain that SES is an approach to studying multi-level system of essential services such as food, fiber, energy, and water. Social-ecological system consists of resource system component, resource unit component, governance component, user component, and the action situation resulting from the dynamics of other components (McGinnis and Ostrom 2014). SocioEcological System is a complex system where human systems, economic systems, and natural systems intertwine and influence each other (Berkes and Folke 1994; Holling 2001). Previous research by Triastono and Lidjang (2007), Bunganen (2013), and Ratumakin et al. (2016) indicated that the complexity of water resource management is a problem of Socio-Ecological System.

Ostrom and McGinnis (2014) explained that SESF is designed to identify the works and critical relationships among components of SES. Ostrom and McGinnis defined five components or sub-system to explain SES: (i) Resource system, a biophysical subsystem that we want to study, for instance, lake, dams, forest, or habitat of fish, (ii). Resource unit, a subsystem explaining the flow of a resource, for instance, water discharge, trees harvested in a period. A resource unit explains amount of resource that flows or is used or extracted for a certain period, (iii). Governance system is a sub-system related to property rights, rules, regulations, and sanctions, (iv). Actors as subsystems explain people involved in such SES include each actor's attributes and how they interact with each other, (v). Action-situation is the result of interaction among components. Action situations can be positive, indicating the improvement of the systems, or negatives indicating deterioration of the system such as conflicts, injustice, etc.

Using the SESF, the study tries to answer questions about the influence of tenurial system on SES performance. Performance here is related to sustainability of resource flow and equity of resource usage. We started by studying action-situation components (conflicts, tensions, sabotage of system) of retention basin. We also include access to groups of community, who are excluded from the system, and who gets access to water in a retention basin.

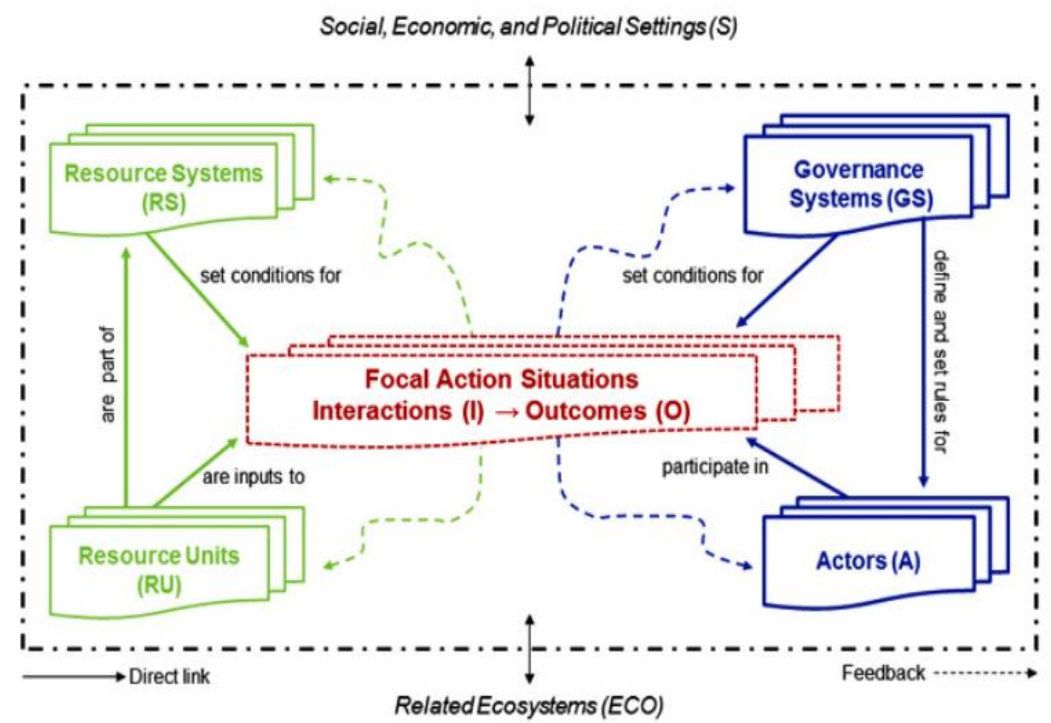

Figure 2. Social ecological framework (McGinnis and Ostrom 2014) 


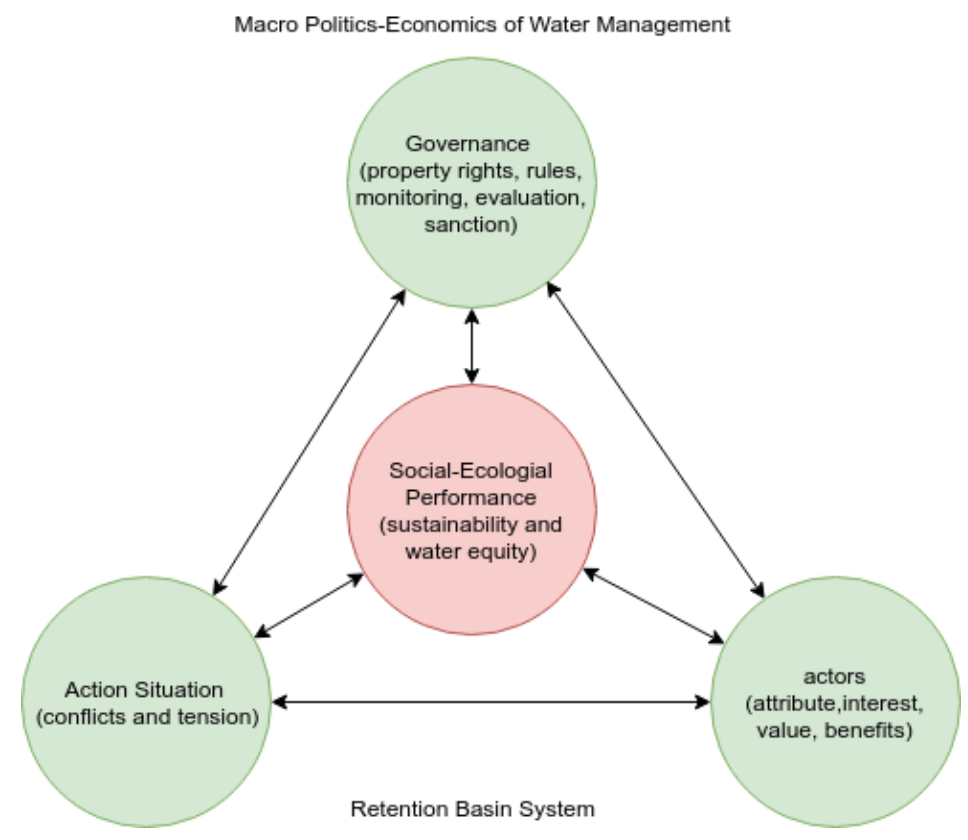

Figure 3. Conceptual framework of the study, adopted from McGinnis and Ostrom (2014)

Table 1. Summary of data collection techniques

\begin{tabular}{|c|c|c|c|c|}
\hline $\begin{array}{l}\text { Type of } \\
\text { data }\end{array}$ & Topics & $\begin{array}{l}\text { Data collecting } \\
\text { techniques }\end{array}$ & Instrument & Source/resource persons \\
\hline \multirow[t]{6}{*}{ Primary } & $\begin{array}{l}\text { Action situation (conflicts, } \\
\text { tensions, sabotage, vandalism) }\end{array}$ & FGD & $\begin{array}{l}\text { Semi-structured questionnaire } \\
\text { guidelines }\end{array}$ & $\begin{array}{l}\text { Village government officials, } \\
\text { female and male farmers, } \\
\text { customary leaders }\end{array}$ \\
\hline & History of retention basins & FGD on history of village & $\begin{array}{l}\text { Semi-structured questionnaire } \\
\text { guidelines }\end{array}$ & $\begin{array}{l}\text { Customary leaders, village } \\
\text { government officials }\end{array}$ \\
\hline & Land use & $\begin{array}{l}\text { Village sketch and aerial } \\
\text { photos }\end{array}$ & $\begin{array}{l}\text { Semi-structured guidelines, } \\
\text { aerial maps }\end{array}$ & Male and female farmers \\
\hline & Land ownership & $\begin{array}{l}\text { Village sketch and aerial } \\
\text { photos }\end{array}$ & $\begin{array}{l}\text { Semi-structured guidelines, } \\
\text { aerial maps }\end{array}$ & $\begin{array}{l}\text { Customary leaders, male and } \\
\text { female farmers }\end{array}$ \\
\hline & $\begin{array}{l}\text { Perception on socio-ecological } \\
\text { performance }\end{array}$ & Seasonal calendars & $\begin{array}{l}\text { Calendar tables, Semi-structured } \\
\text { guidelines }\end{array}$ & Male and female farmers \\
\hline & $\begin{array}{l}\text { Perception on governance of } \\
\text { retention basins }\end{array}$ & FGD & Semi-structured guidelines & $\begin{array}{l}\text { Village government officials, } \\
\text { female and male farmers, } \\
\text { customary leaders }\end{array}$ \\
\hline
\end{tabular}

After studying the action situation, the next step is to gain information related to governance which includes tenurial system, rules, and behavior of actors involved in action-situation. The third step is to study actors involved in conflicts, those who gain benefits, social attributes of each actor, and power relationships among actors. The fourth step of the study is analyzing the overall socioecological performance of the SES. There are two themes studied under socio-ecological performance, sustainable flow of resources, and equity of access. We modified the framework for practical reasons in the study as in Figure 3.

\section{Procedure}

The study is a mixed-methods applying conversion mixed data analysis (Teddlie and Tashakkori 2009). The methods quantify qualitative data and then analyze descriptive statistics and network analysis to find the most significant themes raised by resource persons (Teddlie and Tashakkori 2009). Data was gathered from 8 focused group discussions separating male and female participants in 4 villages. Total participants of 8 different FGDs are 50 people consisting of 21 females and 29 males which are farmers and part of customary leadership in the villages. We also interviewed eight customary leaders, and six male and female village government officials.

We employed Participatory Rural Appraisal such as village history, land use, land ownership, seasonal calendar, and village sketch to dig deeper information from resource persons during discussion. Using participatory rural appraisal instruments we can see the dynamics of discussion, when they agree on some issues, or when they do not agree on some issues. The PRA also can be used to 
build consensus of information among participants (Narayanasamy 2009). To systematize the process during FGD, we divided the discussions of SES into 6 topics or themes, namely conflicts over water, the history of retention basins, land use, land ownership, perception on socio-ecological performance emphasizing on sustainability of water availability and equity of access, and governance of retention basins emphasizing the roles of actors, rules, institutions, and confirmation of land ownership basin retentions SES. All the information gathered is documented in transcripts, sketch maps, a list of participants, and tables of seasonal calendars.

\section{Analytical methods}

We used mixed conversion data methods to analyze significant themes from transcripts. Mixed conversion data analysis is a quantifying-qualitative analysis (Hesse-Biber 2010; Teddlie and Tashakkori 2009). The quantitative technique was by counting frequencies of themes from an interview, dialogue, speech, or text. Hesse-Biber (2010) and Teddlie et al. (2009) explain that quantitative analysis of themes or categories can give significant themes that need to be analyzed further. Both Hesse-Bieber (2010) and Teddlie (2009) suggest an iterative analysis from codified and quantified themes with interpretation of texts in the transcripts.

We employed the process from grounded theory approach using coding technique of themes, sub-themes, and category, or profile data from transcripts as suggested by Creswell (1998). We used open-source software R-QDA (R-Qualitative Data Analysis) to help categorize and code themes from the transcript. We also used spreadsheet Libreoffice Calc to help quantitative analysis of themes (Bree and Galagher 2016).

The procedure of analysis is following procedures suggested by Creswell (1998) as follows: (i) Open coding. In this step, we categorized information by segmenting information. In each category, we looked for a phenomenon related to the SES framework. We look at the whole transcript and code every paragraph and sentence into open categories or code. Similar property (characteristics) or statements will be coded under the code. Extreme phenomenon or statements is categorized under different code. (ii) Categorizing codes. With RQDA categorizing bigger themes can be done after or before open coding is completed. We did categorize codes into 6 themes (conflicts, SES performance, land use, land ownership, governance, history) after we did the open coding process. (iii) Axial coding is a process to link relevant codes contribute or as a result of a central phenomenon. Here, we used logical diagram and tabulate the codes with adjacency matrix (1 to 1 matrix) to find the cause and the result of a central phenomenon.

Then, we went to the next step to identify stories of phenomenon of water conflicts and their impact. To ensure that the stories composed from data analysis are consistent with the transcript, we compared the stories with the transcript of FGDs and find the text that proves the theory constructed from coding process.

\section{RESULTS AND DISCUSSION}

\section{Center phenomenon}

The focus group discussions and interviews were undertaken from June 2018 to September 2019. There was 17 transcripts of code analyzed in this study. The 17 transcripts were coded into 38 thematic codes, and there have been 412 individual paragraphs and statements coded. The second step is to categorize the 38 codes and counting frequencies of each theme and cluster them into 6 categories. Table 2 showed the frequencies of themes mentioned by participants of FGD and interviews.

Qualitative analysis of transcripts resulted in the most frequent themes from FGD and interviews for each category. Under category of resources system, the participants described diverse systems of water resources in the villages. Water sources consist of low wells, deep wells, springs mostly in the cave, and retention basins. The infrastructure of water system is also varied. Some springs and deep wells have piping distribution systems mostly to public taps. But not all wells and springs are equipped with distribution pipes and pumps. Community-built wells usually are not equipped with infrastructures such as pumps or piping. If there are community-built wells equipped with such infrastructure, that is the owner of the wells who buy all the equipment and flow the water to his/her house. In government-built wells, usually equipped with pumps and piping to public tap. However, the infrastructure is not always maintained. Some of the infrastructures such as piping were damaged, and no one cared to repair them. In all villages, most governments built wells do not have institutions or organizations ensuring sustainability of the infrastructure.

Retention basins are the most discussed water system under the category of resource system. All of the retention basins mentioned by participants are under conflicts or tensions. The accessories of the retention basins such as piping are usually damaged or sabotaged by some people to water their own crop gardens or cattle. None of the retention basins have an institution to manage the basin system. After the government at national, provincial, or district level transferred the basins to the village or community, government expected community to selfgovern the basin. The only role of government at national, provincial, or district level is providing maintenance budget for some years (usually 2 or 3 years) to repair the accessories of the basin.

In category of action, conflicts in many forms are the most frequent themes exposed during discussion and interview. In category of actors, landlords are the most frequently spoken by participants as influential figures and perpetrators of water conflicts. Landlords with their affiliates members usually sabotage the piping system to benefit their groups or families. Open conflicts did not occur, sabotage, damaging pipe, or breaking pipe, was the common action by certain groups in the community. Most of the participants suggested that landlords and their affiliates are the perpetrators of sabotage to exclude larger groups to access the water. In governance category, clan ownership is the most issue told by participants. Clan 
ownership is influential and has a strong relation with community-managed resources, ineffective water institutions, and conflicting village government control over retention basins.

The last category analyzed in the study was the socioecological performance of retention basins. In this category, basin condition issues mean sedimentation is the most frequent topic discussed by participants and interviewees. The next theme that came up from the discussion is retention basin water availability. Retention basins are mainly used for agriculture and cattle raising. Only when getting freshwater is very limited, inhabitants in 4 villages fetch water from retention basins. The issues are also related to the distribution challenges themes and equity of access. Not all inhabitants get the same opportunity to access water even in a sub-village. In-equity of water access relates to the conflicts.

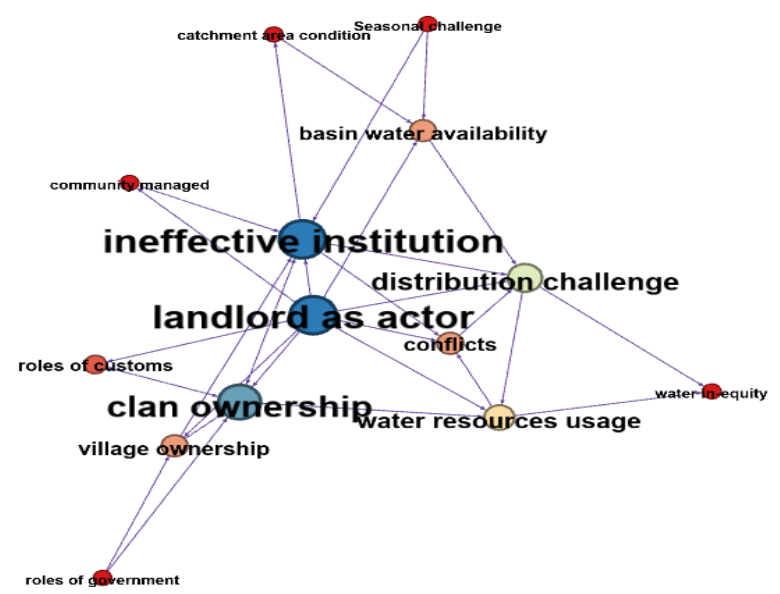

Figure 4. Relationship among selected themes

Table 2. Thematic coding and categorizing results

\begin{tabular}{|c|c|c|c|c|c|c|}
\hline Category & Code & Batuinan & Hansisi & Huilelot & Uiasa & Total result \\
\hline \multirow{3}{*}{ Action situation } & Colonial forest border & 1 & & & & 1 \\
\hline & Conflicts & 4 & 7 & 1 & 8 & 20 \\
\hline & Land and forest conflicts & 1 & & & 1 & 2 \\
\hline \multirow{2}{*}{ Actors } & Landlord ${ }^{1}$ & 16 & 4 & 2 & 3 & 25 \\
\hline & Roles of government & & 3 & 2 & 1 & 6 \\
\hline \multirow[t]{2}{*}{ Gender } & Female participation & 1 & 5 & 2 & 4 & 12 \\
\hline & Male domination & 1 & & & 2 & 3 \\
\hline \multirow[t]{8}{*}{ Governance } & Clan ownership & 11 & 6 & 7 & 10 & 34 \\
\hline & Community managed & 5 & & 2 & 6 & 13 \\
\hline & Customary rules on natural resources & & & 6 & 5 & 11 \\
\hline & Ineffective institution & 2 & 11 & 3 & 5 & 21 \\
\hline & Land ownership & 1 & & & 1 & 2 \\
\hline & Roles of churches & 1 & 1 & & & 2 \\
\hline & Roles of customs & 1 & & & & 1 \\
\hline & Village ownership & 5 & 1 & 1 & 6 & 13 \\
\hline \multirow[t]{12}{*}{ Resource system } & Climate and weather condition & 2 & 1 & 1 & 3 & 7 \\
\hline & Population number & 1 & & & & 1 \\
\hline & Retention basin & 12 & 8 & 5 & 10 & 35 \\
\hline & Spring & 1 & 3 & 2 & 6 & 12 \\
\hline & Unfit technology & & & 1 & & 1 \\
\hline & Users & 7 & 1 & 2 & & 10 \\
\hline & Water consumption & 1 & 3 & & & 4 \\
\hline & Water cost & 5 & 5 & 1 & 7 & 18 \\
\hline & Water fetch technology & 2 & 2 & & & 4 \\
\hline & Water resource usage & 16 & 24 & 5 & 18 & 63 \\
\hline & Water tank & 2 & 1 & 1 & & 4 \\
\hline & Well & 6 & 2 & 2 & 4 & 14 \\
\hline \multirow[t]{9}{*}{ SE-performance } & Basin condition & 1 & 9 & 5 & 10 & 25 \\
\hline & Basin water availability & 3 & 2 & 2 & 3 & 10 \\
\hline & Catchment area condition & 1 & & & 1 & 2 \\
\hline & Distribution challenge & 1 & 4 & 3 & 3 & 11 \\
\hline & Negative impact of water system & & 2 & 3 & 1 & 6 \\
\hline & Seasonal calendar & & & 1 & & 1 \\
\hline & Spring condition & & & 6 & 1 & 7 \\
\hline & Water equity & 2 & & 1 & & 3 \\
\hline & Well condition & 4 & 1 & 1 & 2 & 8 \\
\hline Total result & & 117 & 106 & 68 & 121 & 412 \\
\hline
\end{tabular}

Note: ${ }^{1}$ Landlords or tuan tanah in Bahasa Indonesia and local dialects could mean the owner of the land. In customary terms, tuan tanah is sometimes associated with the heir of customary or ancestral land. The landlords or tuan tanah usually control large parcel of land and can give use rights to relatives or those who needs land to plant food crops. In other custom for instance in Timor, in the Atoni pah Meto (Timorese) customs and tenurial system, a landlord is not the land owner. The land belongs to his ancestor, and the landlord play the roles as the custodian or steward of the land (Ataupah, 1994). Explanation of the terms is explained in the Discussion section. 
Table 3. Relational matrix of selected themes

\begin{tabular}{|c|c|c|c|c|c|c|c|c|c|c|c|c|c|c|c|c|}
\hline & \multirow[b]{2}{*}{ Cause } & \multicolumn{15}{|c|}{ Results } \\
\hline & & $\mathbf{A}$ & B & $\mathbf{C}$ & D & $\mathbf{E}$ & $\mathbf{F}$ & $\mathbf{G}$ & $\mathbf{H}$ & $\mathbf{I}$ & $\mathbf{J}$ & $\mathbf{K}$ & $\mathbf{L}$ & $\mathbf{M}$ & $\mathbf{N}$ & $\mathbf{O}$ \\
\hline $\mathbf{A}$ & Conflicts & & & & & & & & & & & & 1 & & & \\
\hline B & Landlord & 1 & & & 1 & 1 & 1 & & 1 & 1 & 1 & & 1 & & & 1 \\
\hline $\mathbf{C}$ & Roles of government & & & & 1 & & & & & 1 & & & & & & \\
\hline D & Clan ownership & & & & & & 1 & & 1 & & & & & & & 1 \\
\hline $\mathbf{E}$ & Community managed & & & & & & 1 & & & & & & & & & \\
\hline $\mathbf{F}$ & Ineffective institution & 1 & & & 1 & & & & & & & & 1 & & & \\
\hline $\mathbf{G}$ & Roles of churches & & & & & & & & & & & & & & & \\
\hline $\mathbf{H}$ & Roles of customs & & & & 1 & & & & & & & & & & & \\
\hline $\mathbf{I}$ & Village ownership & & & & 1 & & 1 & & & & & & & & & \\
\hline $\mathbf{J}$ & Basin water availability & & & & & & & & & & & & 1 & & & \\
\hline K & Catchment area condition & & & & & & & & & & 1 & & & & & \\
\hline $\mathbf{L}$ & Distribution challenge & & & & & & & & & & & & & & 1 & \\
\hline $\mathbf{M}$ & Seasonal calendar & & & & & & & & & & 1 & & & & & \\
\hline $\mathbf{N}$ & Water in-equity & & & & & & & & & & & & & & & \\
\hline $\mathbf{O}$ & Water resources usage & & & & & & & & & & & & & & 1 & \\
\hline
\end{tabular}

\section{Selective themes and their relations}

After finding the central phenomenon from the open code and categorization, we look back to the transcript and find the logic of the stories described in each transcript. We found 15 themes relevant to central phenomenon and created an adjacency matrix to relate the direct cause and result of each theme as presented in Table 3.

We then create visualization with Gephi 0.9.2, software for social network analysis where the visualization is presented in Figure. 4. In Figure 4 we can see the landlord as actor, ineffective institution, and clan ownership as the center of themes network. It means the three themes are the most influential factors of the dynamics of retention basin socio-ecological system.

\section{Discussion}

It is likely that the socio-ecological performance in terms of sustainability of water flow and equity of water access is influenced by landlords' roles. In all retention basins development, land was given by landowner or landlords through written agreement. Some landlords even got compensation for the land, even he still control the land. The retention basins usually only used some part of landlords' land, yet the landlord still has control over the storage and piping facilities of a retention basin. By controlling these facilities, landlords are able to exclude other users for his benefits.

The use of claim of ancestral land by landlords to exercise his power to control natural resources and infrastructure probably is the opposite of the original values of custodianship or stewardship of land and resources. Ataupah (1995) explains that in Timor, a landlord is a father of his community. As a good father, a landlord who is the descent of the first dweller, has the moral obligation to ensure the life of its community. Landlord would give lands to those who hunger, thirsty, and cold. By giving parcels of land, he protects all the people living in his domain. However, giving land to produce food, build a house, or access to water, doesn't mean that the landlord transfers ownership to his people. The landlord still has control of the land, because land is social goods, not private goods. If one does not need land, they should give back the land to the landlords so the landlord can give the land to others who need it.

In Semau, we found that the value of natural resources as social or public goods still exists in the old water resources such as the spring, spring in the cave, and old wells where in the past people fetch water manually. However, new built resources such as retention basins, constructed deep well equipped with pump and piping systems become a contested arena between landlord and commoners. In the report written by Hormat et al. (2015), in the past, similar values and roles of the landlords have similarities as Ataupah (1995) explain in the context of Timor where the landlords have moral obligation to ensure the subsistence of their people. We suggest that it might have been changed in values and roles of landlords in Semau.

It is also quite obvious that whenever water resource is used for domestic subsistence use (drinking, washing) the conflict over water resources is much lower or does not exist. Conflict or tension occurred only when water resources are used for commercial agriculture. Retention basins are mostly used for agriculture. These findings are similar to the study done by Jocom (2016) in Timor and Ratumakin (2016) in Timor and Alor that conflict on water resources rarely happens where water resources is natural and traditionally used for domestic purposes.

This might be in line with the explanation of Blaikie in Ribot and Peluso (2003) that technology, capital, markets, knowledge, authority, social identities, and social relations can shape or influence access. And also, the tendency of government to uniform approach of community-based resources management might be influential in changing the behavior and values of traditional institutions that are landlords authority, claim over ancestral land, roles and values. Blaikie (2006) has critical view on the uniformity of government's community-based natural resources management program. Blaikie (2006) explains that government program tends to simplify or even hide the 
complexity within communities. Hiding and simplifying the complexity could have an implication to more marginalization of already marginalized groups and enforcing the already have power (Blaikie 2006).

The phenomenon of conflicts on water from retention basins can also be explained under hydro-social territorialization concepts introduced by Swyngedouw (2009) and Boelens (2016). Boelens (2016) defined hydrosocial territory as: "the contested imaginary and socioenvironmental materialization of a spatially bound multiscalar network in which humans, water flows, ecological relations, hydraulic infrastructure, financial means, legaladministrative arrangements, and cultural institutions and practices are interactively defined, aligned and mobilized through epistemological belief systems, political hierarchies and naturalizing discourses."

This article explains the first finding of our study. Further investigation will be needed to understand the relation of external and internal factors enforcing the dynamics of social-ecological system as suggested by Armitage (2005), Ostrom and McGinnis (2014), and Boelens (2016). Socio-ecological System particularly the governance of water changes when water infrastructures are built in an area. The external factors and the process of territorialization need to be investigated further in the political-economic context in terms of policy, program influencing the SES of retention basin in Semau Island.

\section{REFERENCES}

Ali A, Yazar A, Abdul Aal A, Oweis T, Hayek P. 2010. Micro-catchment water harvesting potential of an arid environment. Agricultural Water Manag 98 (1): 96-104. DOI: 10.1016/j.agwat.2010.08.002.

Armitage D. 2005. Adaptive capacity and community-based natura resource management. Environ Manag 35 (6): 703-715. DOI: 10.1007/s00267-004-0076-z.

Ataupah H. 1995. Land Tenure di Daerah Aliran Sungai Mina. Kupang: NTT Watershed Management Planning Project. [Indonesian]

Balai Wilayah Sungai Nusa Tenggara II. (n.d.). SISDA BWSNT2. http://sisda.bwsnt2.org/index.php/embung_kecil/kabupaten/1 [Indonesian]

Berkes F, Folke C. 1994. Linking Social and Ecological Systems for Resilience and Sustainability. Beijer International Institute of Ecological Economics, Sweden.

Blaikie P. 2006. Is small really beautiful? Community-based natural resource management in Malawi and Botswana. World Dev 34 (11): 1942-1957. DOI: 10.1016/j.worlddev.2005.11.023.

Boelens R, Hoogesteger J, Swyngedouw E, Vos J, Wester P. (2016). Hydrosocial territories: A political ecology perspective. Water Int 41 (1): 1-14. DOI: 10.1080/02508060.2016.1134898.

Boers TM, Zondervan K, Ben-Asher J. 1986. Micro-Catchment-WaterHarvesting $(\mathrm{MCWH})$ for arid zone development Author links open overlay panel. Agric Water Manag 12 (1-2): 21-39. DOI: 10.1016/0378-3774(86)90003-X.

BPS Kabupaten Kupang. 2019. Kabupaten Kupang dalam Angka 2019. Badan Pusat Statistik Kabupaten Kupang, Kupang. [Indonesian]
Bree R, Galagher G. 2016. Using Microsoft Excel to code and thematically analyse qualitative data: A simple, cost-effective approach. AISHE-J 8 (2): 2811-28114.

Bunganaen W. 2013. Analisis kinerja embung oelomin di Kabupaten Kupang, Pemkab Kupang, Kupang. [Indonesian]

Creswell JW. 1998. Qualitative Inquiry and Research Design: Choosing Among Five Traditions. SAGE Publications, Inc., London.

Falkland A, Custodio E. 1991. Hydrology and water resources of small islands: A practical guide: a contribution to the International Hydrological Programme, IHP-III, Project 4.6. Unesco, Paris.

Hesse-Biber SN. 2010. Mixed Methods Research: Merging Theory with Practice. Guilford Press, New York.

Holling CS. 2001. Understanding the complexity of economic, ecological, and social systems. Ecosystems 4 (5): 390-405. DOI: 10.1007/s 10021-001-0101-5.

Hormat G, Heo M. 2015. Profil Sistem Sumber Daya di Desa Uiboa, Desa Uitiuh Tuan, Desa Batuinan, dan Desa Uitiuh Ana di Pulau Semau. Perkumpulan Pikul, Kupang. [Indonesian]

Jocom H, Kameo D, Utami I, Kristijanto A. Ign. 2016. Air dan konflik: Studi kasus Kabupaten Timor Tengah Selatan. Jurnal Ilmu Lingkungan 14 (1): 51 61. DOI: 10.14710/ji1.14.1.51-61.

Kaho NR. 2019. Laporan Bentang Lahan Pulau Semau. Geng Motor Imut, CIS Timor, Perkumpulan Pikul, Kupang Batanam, GEF-SGP Phase VI. [Indonesian]

Kerr J. 2007. Watershed management: Lessons from common property theory. Intl J Commons 1 (1): 89-109. DOI: 10.18352/ijc.8.

Kompas. 2017. March 15. Jokowi Didesak Bangun 3.000 Embung di NTT.

https://properti.kompas.com/read/2017/03/15/090000621/jokowi.dide sak.bangun.3.000.embung.di.ntt

McGinnis MD, Ostrom E. 2014. Social-ecological system framework: Initial changes and continuing challenges. Ecol Soc 19 (2): 30. DOI: 10.5751/ES-06387-190230.

Narayanasamy N. 2009. Participatory Rural Appraisal, Principles, Methods and Application. SAGE Publications India Pvt Ltd., New Delhi, India.

Notoatmojo B, Rivai R. 2001. Optimasi pengembangan embung di Indonesia. The Winners 2 (1): 12. DOI: $10.21512 /$ tw.v2i1.3795 [Indonesian]

Pradhan D, Ancev T, Drynan R, Harris M. 2011. Management of water reservoirs (embungs) in West Timor, Indonesia. Water Resour Manag 25 (1): 339-356. DOI: 10.1007/s11269-010-9702-0.

Ratumakin PAKL, Kuswardono PT, Heo MJ, Weo YUP. 2016. Pengetahuan Lokal dalam Keberlanjutan Pengelolaan Air. Perkumpulan Pikul, Kupang, Indonesia. [Indonesian]

Ribot JC, Peluso NL. 2003. A theory of access. Rural Sociol 68 (2): 153181. DOI: 10.1111/j.1549-0831.2003.tb00133.x.

Solomon S. 2007. Climate change 2007: The Physical Science Basis: Contribution of Working Group I to the Fourth Assessment Report of the Intergovernmental Panel on Climate Change. Cambridge University Press, Cambridge, New York.

Swyngedouw E. 2009. The political economy and political ecology of the hydro-social cycle. J Contemporary Water Res Educ 142 (1): 56-60. DOI: 10.1111/j.1936-704X.2009.00054.x.

Teddlie C, Tashakkori A. 2009. Foundations of mixed methods research: Integrating quantitative and qualitative approaches in the social and behavioral sciences. SAGE, Los Angeles.

Triastono J, Lidjang I. 2007. Scoping study: Pemanfaatan embung di Pulau Timor. Komunikasi Hasil-Hasil Penelitian Pertaniaan dan Peternakan dalam Sistem Usaha Tani Lahan Kering. Kupang, Indonesia. [Indonesian]

UU no 1 tahun 2014. Undang-undang Pesisir dan Kelautan. Pub. L. No. $1 / 2014$. [Indonesian] 